\title{
Popular Communication Audiences: A Historical Research Agenda
}

\author{
Richard Butsch \\ Rider University
}

\begin{abstract}
Popular communication research can benefit from a historical approach. Consistent with current approaches, historical research is contextual (e.g., looking at actual audiences in natural settings). It is also comparative. Comparing radio to television helps to highlight by contrast features not otherwise noticed, including assumptions we have made unawares. Historical research is developmental, allowing us to understand how things come about and change. Examples from the author's own research illustrate the benefits and surprising discoveries historical research can offer. Historical research has developed very unevenly across media and topics. There is a good deal of film history but a paucity of radio history; a good bit on media industry and technology, but little on audiences. This leaves room for a great deal of valuable history yet to do.
\end{abstract}

Various scholars have advocated media histories. Interest in media has been growing among historians for some time as part of a more general interest in popular culture, cultural history, and the 20th century. Some years back, radio historian Susan Douglas (1992) proposed historians launch efforts at documenting a history of media audiences. Although film studies has always included a sizable number of scholars interested in film history, film historian Robert C. Allen (1990) similarly proposed further historical studies of movie audiences. Michael Schudson (1991) noted that communication history is "woefully underdeveloped" and that the history of reception is "by far the most elusive." Media, Culture and Society periodically has published special issues of historical research, and David Morley (1986) has noted the value of historical studies of media audiences. Most recently, Sonia Livingstone (2002) argued for a historical perspective to understanding changing media environment—as she phrases it, "looking back, the better to look forward."

Requests for reprints should be sent to Richard Butsch, Department of Sociology, Rider University, Lawrenceville, NJ 08648. E-mail: butsch@rider.edu 
In this essay I advocate more historical audience research. Historical research has advantages for studying popular communication audiences. Although the insights gleaned about audiences also may be achieved through other methods, the historical perspective makes them easier to achieve for several reasons.

- Historical research is contextual.

- Historical research is comparative.

- History can also reveal development over time.

- Historical research helps to clarify assumptions, concepts, and categories.

Historical research is contextual. It focuses on actual audiences in natural settings rather than theoretically or "laboratory" constructed audiences. In situating audiences in their social and historical context, we may understand media use as well as contemporary interpretations of media use. This helps to highlight audience practices rather than media effects. It also helps to recognize that audience-medium interactions are embedded in other social relations and cultural practices.

Historical research is comparative. Historical research can compare audiences of different eras, such as radio in the 1920s to television in the 1950s and the Internet in the 1990s. This comparative approach helps to reveal characteristics of a practice by the contrast to similar practices of a different time and, in this case, of a different medium at the same stage of development. For example, the considerable criticism directed at television over several decades contrasts markedly to the relatively mild criticism of radio during its heyday. This in turn allows us to discern sources of difference and to trace change as it evolves over time.

History can also reveal development over time. Audiences for movies, radio, and television each underwent developments. The demographics of movie audiences as well as the talk about audiences changed from the nickelodeon era to the 1920s to the Depression, and so on. This approach helps to remind us that audiences are not static but vary in their identity and their practices across time and location.

Historical research helps to clarify assumptions, concepts, and categories. Statements about audiences often contain implicit assumptions of some prior historical condition. For example, displacement hypotheses worry that television or the Internet displaced some activity that children previously engaged in and benefitted from. For many years, most discussions of audiences have presumed attention, ignoring the real-life fact that people often do not look at the television. Ellen Wartella and Byron Reeves (1985) noted the collective amnesia about the history of audience research. Awareness of earlier work would help to understand and reformulate concepts we use today. 


\section{WHAT WE KNOW TODAY}

To illustrate some of the benefits of popular communication research, let me discuss some of the lessons I have learned from my own historical research. First, I have learned to recognize the plurality and diversity of audiences. We used to think of "the audience" as singular, individual, passive, and fixed in time. Even while knowing at one level that there are many different kinds and segments of audiences, we tend to talk in terms of the audience, as evident in the titles of many books and articles on the subject. Just as feminists began to re-examine the category of "woman" and recognize its plurality and diverse parts, we need to re-examine the category of audience. Since Michel Foucault (1978) first demonstrated the value of interrogating basic categories, several such categories have been deconstructed, including the categories of "homosexual," "woman," "race," and "the worker," resulting in dramatic new research developments (Baron, 1994; Fields, 1982; Riley, 1988). Cultural studies scholars have examined the category of "television audience," and some recommended eliminating the concept altogether (for example, Allor, 1988; Ang, 1991; Hartley, 1987; Morres, 1993; Silverstone, 1990). In my own work I have looked beyond this one medium to explore the general term of audience and have found the plural audiences to be more useful.

Audiences are typically conceived in terms of reception. Within that framework the emphasis has been on audiences composed of individuals, each engaged in the same practice of reception. The audience could be conceived as singular because members were conceived as alike. The audience as a whole was no different than an individual member; collectively or individually, the audience was singular. More recent approaches arguing for polysemic reception suggest a plural definition is better suited for the concept. History too indicates the plural nature of audiences.

Audiences are not just composed of individuals, but also of diverse groups that may have different or even conflicting interests. This is obvious when one reads about battles between those in the pit and those in the boxes of early 19th-century theater (Butsch, 1995). Once we see these diverse groups, we then also notice when a group is absent, as when some mid-19th-century theaters began to exclude rowdy young working-class male audiences and to seek respectable female and more profitable middle-class audiences. This also alerts us to ask, "where did the missing groups go?" leading to a line of questions involving displacement, competing media, and niche markets. At least some of these rowdies found theaters that continued to accept them and their audience practices. As a result, 19th-century theater evolved into several different markets, different audiences attending different theaters (McConachie,1992). There were even different audiences in the same place at different times (Butsch, 2000). Moreover, movie exhibitors and later radio and television scheduled shows to fit the times when men, women, or children might be the principal audience. Therefore, we need to be cautious when generalizing about the movie audience or the radio audience, because there are many 
different ones. Ignoring the differences means missing an opportunity to learn about the nature of audiences.

History gives nuance and depth to other concepts. David Morley (1986) observed that to appreciate television audiences we needed to understand the context of families and home where most people watch. Roger Silverstone (1990) used the term embedded to refer to the nested character of television viewing in the home (p. 174). Recognizing that television viewing is set within other activities emphasizes that audiences are dividing their attention, and therefore their attention to television is partial or interrupted. The concept of embeddedness actually is a special case of an older recognition from leisure time studies that people often engage in two or more activities simultaneously (Harvey, 1990). Some activities may be lesser projects nested within larger projects nested within larger projects (Schutz, 1967). Embeddedness has been used as a term to suggest the family is the primary practice and viewing the secondary. Television studies often reversed the priority. Regardless of the priority, the important matter is to recognize that activities are not isolated and one may influence another. As an alternative to embedded, we may say the activities are linked.

The family setting is only a recent example of a long tradition of audiences embedded in or linked to other activities. Watching television in a dorm room or in public places such as a bar or a waiting room is linked too. Even theater and movie audiences have a history of being embedded in other activities. Court theater in England (Cook, 1981; Gurr, 1987) and France (Johnson, 1995) and 17th-century opera in Italy (Rosselli, 1984) were notable for the degree to which the performance was secondary to privileged audiences carrying on their business or court intrigue or match-making. The performances to which more attention was paid were who came and went, with whom, and what business was transacted. Similarly in Jacksonian theater, the camaraderie and antics among working-class men in the pit were as important as the performance on stage (Butsch, 2000). In the early days of movies, nickelodeons were described as social clubs (Hansen, 1991). Despite the location in a theater, in all these instances people defined the situation as socializing among the audience as much or more than attending a performance.

The degree to which audiences attended to the entertainment depended on its novelty to them. Time after time, historical research has revealed that audiences are very attentive to new media but become inattentive as the medium becomes mundane and taken for granted. This was true for radio and television in the home, as well as for wealthy regular theatergoers whose inattention was a form of conspicuous consumption (Butsch, 2000).

All this indicates that we must understand audiences as situational and that definitions of situations are historically contingent. What it means to be an audience or to use a medium depends on the particular time and place. Going to drama theater in New York City in 1830 meant entering a masculine realm where one could expect drinking, smoking, prostitution, and rough and boisterous behavior. By the 
1890s it was a feminine situation (Butsch, 2000). Going to the nickelodeon in 1908 was informal and social; going to a movie palace in 1920 was formal and reserved (Butsch, 2000).

The classic distinction between active and passive audiences also gains greater depth through historical comparison. "Active" and "passive" have been conceived in psychological terms, of mentally active or passive, based on a presumed interaction between the show and the audience. The "ethnographic turn" has been an antidote to this (Nightingale, 1989; Turner, 1992). It has emphasized that television viewing is not passive, that it is embedded in social relationships and thus not individualized and not solely about viewer and viewed, but also viewer and viewer. Historical research complements this by extending these ideas across a long time horizon and embedding them in more varied and broader contexts.

Historical research also helps to move beyond the idea of audience members being active individually. The difference between individual and collective action by audiences is of enormous importance. Audiences acting collectively become political forces, alternately constituting public spheres, or exercising the power of the crowd. The tradition of plebeian audience sovereignty in European and American theater that reigned until the mid-19th century is an example (Butsch, 2000). Within this tradition, audiences were quite vocal and periodically exercised their collective power to enforce their will on entertainers. They were sociable among themselves, and their collective behavior represented aspects of a public sphere and of crowd action (Butsch, 2000). According to film historian Miriam Hansen (1991), early nickelodeon audiences constituted a public sphere. Today the community and collective nature of Internet chat rooms may be better understood by considering them in comparison to these historical precedents of audiences.

History also makes us more conscious of how audiences are talked about. Post-structuralism has made us sensitive to historical documents as representations rather than transparent descriptions. This is a wholly new consideration, to study how audiences are socially constructed. This leads to recognizing the degree to which scientific discourse on audiences has been shaped by public discourse and considering what about audiences have been neglected since they have been absent from public discourse.

\section{WHERE TO GO FROM HERE}

Most media history has not focused on audiences. The history of audiences has been ancillary and incidental to historical research. After noting an interesting incident of audiences, the famous chronicler of New York City theater, George C. D. O'Dell (1927), remarked that maybe we should study theater history through its audiences. But little came of that off-hand comment. With a few exceptions, most history of audiences is incidental, incorporated into studies of content, exhibition, 
production, or some larger cultural history. As a general rule, a more systematic study of audiences is in its infancy.

Research is developed very unevenly among media such that some media have been less researched than others. Movie-audience research is relatively well developed, even though it too is undeveloped beyond the nickelodeon era. Television-audience histories are next well developed. Radio is even less. Ironically, other than short messages woven into histories of the music industry or studies of teenagers or delinquency, popular-music audiences have received almost no attention. One would have thought that the large amount of work on youth culture and cultural resistance would have generated more historical study of youth as audiences. Yet this has remained relatively undeveloped.

Lastly, the humdrum is less researched than times of dramatic change. Historical research that has been done has focused more on moments of innovation-for example, the beginning of movies in the nickelodeon days or the reactions of people to sound films. On the other hand, we have relatively little on the heyday of movies once movie-going had settled into a widespread habit. These times are difficult to document. Documentation of any audiences is scarce. But documentation when audiences are not noteworthy is even thinner. People simply do not record what is not noteworthy. Nevertheless, studying such times is important if only to check our assumptions and find out what is underneath the seemingly unremarkable. Who knows? Changes may be brewing underneath. They also are times when the medium is at its most popular and thus most influential, making what audiences do more important than the times of apparent change. For these unremarkable times it is also important to differentiate audiences. We should not presume uniformity but be alert to different customs in different places.

\section{REFERENCES}

Allen, R. C. (1990). From exhibition to reception: Reflections on the film audience in film history. Screen, 31, 347-356.

Allor, M. (1988). Relocating the site of the audience. Critical Studies in Mass Communication, 5, 217-233.

Ang, I. (1991). Desperately seeking the audience. London: Routledge.

Baron, A. (1994). Gendered subjects: Re-presenting "the worker" in history. Princeton, NJ: Institute for Advanced Studies.

Butsch, R. (1995). American theatre riots and class relations, 1754-1849. Theatre Annual, 48, 41-59.

Butsch, R. (2000). The making of American audiences from stage to television, 1750-1990. Cambridge, England: Cambridge University Press.

Cook, A. (1981). The privileged playgoers of Shakespeare's London, 1576-1642. Cambridge, England: Cambridge University Press.

Douglas, S. (1992). Notes toward a history of media audiences. Radical History Review, 54, 127-138.

Fields, B. (1982). Ideology and race in American history. In J. M. Krousser \& J. McPherson (Eds.), Region, race and reconstruction. New York: Oxford University Press. 
Foucault, M. (1978). The history of sexuality (R. Hurle, Trans.). New York: Pantheon.

Gurr, A. (1987). Playgoing in Shakespeare's London. Cambridge, England: Cambridge University Press. Hansen, M. (1991). Babel and Babylon. Cambridge, MA: Harvard University Press.

Hartley, J. (1987). Invisible fictions: Television audiences, paedocracy, pleasure. Textual Practice, 1, $121-138$.

Harvey, A. (1990). Time use studies for leisure analysis. Social Indicators Research, 23, 309-336.

Johnson, J. (1995). Listening in Paris. Berkeley: University of California Press.

Livingstone, S. (2002). The changing nature of audiences: From mass audience to the interactive media user. In A. Valdivia (Ed.), Blackwell companion to media studies. London: Blackwell.

McConachie, B. (1992). Melodramatic formations. Ames: University of Iowa Press.

Morley, D. (1986). Family television. London: Comedia.

Morres, S. (1993). Interpreting audiences. Thousand Oaks, CA: Sage.

Nightingale, V. (1989). What's "ethnographic" about ethnographic audience research. Australian Journal of Communication, 16, 50-63.

O'Dell, G. C. D. (1927). Annals of the New York stage. New York: Cambridge University Press.

Riley, D. (1988). Am I that name: Feminism and the category of "women" in history. Minneapolis: University of Minnesota Press.

Rosselli, J. (1984). The opera industry in Italy from Cimarosa to Verdi. Cambridge, England: Cambridge University Press.

Schudson, M. (1991). Media context. In K. Jensen \& N. Jankoski (Eds.), A handbook of qualitative methodologies for mass communication. London: Routledge.

Shutz, A. (1967). Phenomenology of the social world. Evanston, IL: Northwestern University Press.

Silverstone, R. (1990). Television and everyday life. In M. Ferguson (Ed.), Public communication: The new imperatives. Beverly Hills, CA: Sage.

Turner, G. (1992). British cultural studies. London: Routledge.

Wartella, E., \& Reeves, B. (1985). Historical trends in research on children and the media, 1900-1960. Journal of Communication, 35(2), 118-133. 